\title{
The Impact of Social Unrest on Property Values in Kano Metropolis, Nigeria.
}

\author{
Orekan, Atinuke Adebimpe \\ Department of Estate Management, College of Environmental Sciences, Bells University of Technology, Ota, \\ Ogun State.
}

\begin{abstract}
Kano is one of the oldest settlements in Nigeria. Its growth in the past had been based on the utilisation of its natural resources and, in modern times, it still maintains its high population due to impressive infrastructural facilities, and the sustained stable market it provides for both manufactured and semi-processed goods. But, the recent upsurge in the threat of Boko Haram in the Northern part of the country has had a major impact on the economy of Kano metropolis. The aim of this paper is to determine the effects of this crisis on the rental and market value of properties when compared to previous years. In attaining this aim, questionnaires were administered to all the estate surveying and valuation firms which are about 35 in number. Out of the 35 questionnaires that were distributed, only 27 were retrieved. Interviews were also conducted with 107 property owners. These property owners were randomly selected from the various estate firms' management portfolio. It was found out that the rental value of properties had fallen due to mass movement of people from this region to other safe areas. It was also established by these property owners that most of the properties affected are residential and are in areas like Ring road, Hotoro, Tokarawa, Naibawa, Selleri quarters, Gwarzo road, Farm centre, Sharada, Unguwar Uku. Presently, the indications are that properties are losing their values in Kano State. It is recommended that government should beef-up security in this area so as to give property owners the confidence to remain and continue to invest in property development.
\end{abstract}

Keywords: rental value, property market, property owner, Kano

\section{Introduction}

Nigeria has experienced four major threats to her survival as a nation since gaining her political independence in 1960. These threats were the Nigerian Civil War (1967-1970), the June 121993 crisis following the annulment of the presidential election results by the military, the violent uprising by militant groups in the oil producing region of the Niger-Delta and the frequent and increasingly violent sectarian and ethnic conflicts, (BOKOHARAM) which have led to the deaths of several thousands of people.

The Boko Haram insurgency mostly in the northern parts of the country is the latest major crisis to threaten the political stability of Nigeria. This is a kind of crisis that Nigeria has not experienced before. From study, it is difficult to totally classify it as an ethnic or a sectarian conflict; the crisis also has economic undertones. Meanwhile, escalation of crisis is blamed on government neglect of its responsibility in meeting the basic needs of the people and its slow response to the security issues involved. The crisis, as to be expected, has had negative effects on the society and the economy far beyond the areas where the insurgents have been operating. Indeed, the social, political and economic effects of the crisis are felt throughout the country.

Abuja, Lagos and Kano city region is the commercial nerve centre of the North and the second largest industrial centre after Lagos in Nigeria. Presently there are over 400 privately owned, medium and small scale industrial establishments. Likewise, there are over 40 branches of commercial banks, quite a number of branches of insurance companies and brokerage firms with impressive infrastructural facilities. As the largest commercial centre in the North, it provides a stable market for both manufactured and semi-processed goods. The volume of trading activities conducted on a daily basis in such local markets as Kwanar singer, KantinKwari, Kurumi and Dawanu, is a proof of the metropolis' potentials as a market for various products. These have resulted in high population densities in this city; it has also helped Kano state a lot in terms of property development because land is highly sought after www.kano.gov.ng.

With the booming business activities in Kano, property investors grew up every day to meet up with the demand of populace. This made property investment to be lucrative and many people acquired property in the state and property values shot up. Presently, Nassarawa GRA, Muritala Mohammed Way, Ibrahim Taiwo Road, Civic Centre, Bompai command the highest property rental and sales value either residential or commercial purposes. Likewise, Sharada, Maganda, Bompai ( Industrial area) command high property rental and sales value for industrial purposes.

Rental value is the fair market value of property while rented out in a lease. More generally, it may be the consideration paid under the lease for the right to occupy. It is also the monetary return which an investment in property can be reasonably expected to command for the use of the particular property Kuye, (2003). It is also 
the amount which a property will command on a weekly, monthly, quarterly or yearly basis. With the dynamic forces of the market, rental value on property can be determined easily. These forces majorly are the demand and supply forces. With the high population demanding for more properties, investors invest in properties to meet up with the demand.

However, the property market is very sensitive to happenings in the social and political arena in any country. A cursory look shows that the Boko Haram crisis seems to have had significant impacts on the property market in Kano metropolis in recent times. Therefore, the aim of this study is to determine the impact the Boko Haram insurgency has had on property rental and sales value in Kano metropolis. The study also wants to find out if it is still possible under the prevailing conditions in Kano for an investor to maximise his profit on property as compared to a few years back.

\section{Literature Review}

Violence in any way affects land and housing in a very subtle or direct manner. When there is an increase in rents on properties and in housing values in one part of a city and there is a fall in prices and land values in some parts, people will prefer to invest in properties where land values are high. Property is known to have an edge over inflation; this prompts a lot of investors to put their income in property rather than in other forms of investment.

Kano being the second largest city in Nigeria after Lagos, a lot of people opted for and migrated to Kano. With this more investors invested in property to accommodate the growing population in the metropolis. There was a high increase in property values and rental value increased almost every two years. The most valuable asset to investors (both indigene and foreign) was property. Many of the homeowners depend on property value growth to generate the funds to re- invest in other businesses. Kano was experiencing a boom period up till the middle of 2011.

The "bust" period (this is a period of negative growth in the cycle) started towards the end of 2011. Apart from the economic depression throughout the world, which Nigeria as a nation is still battling with, there was also a fall in house prices as a consequence of the first attack by the Boko Haram sect.

Despite the effect of social unrest on property values, sales and rental values according to Anas, 2003 of landed property could be arrived at by looking at many indicators like accessibility, transportation, nearness to school, place of work, place of worship, market, hospital etc. To others, one of the major implications of persistent conflicts is the insecurity of lives and properties which tend to hinder foreign economic relations to jumpstart the economy Adeyemi,(2006).This is also supported by Babangida, (2002) who believed that the overall consequences of social crises, especially ethnically and religiously inspired violent clashes are threat to security of life and properties, domestic and foreign investments with continuous capital flight, and loss of confidence in the economy. Eventually, this may lead to increase in the level of poverty in the country. It could also be determined by the components and elements that form part of the building like ceiling, roof, door, decoration finishes, windows, external and partition walls. In addition, the value or worth of a real estate could be arrived at by looking at the public utilities. Facilities and services go a long way in providing a conducive environment for healthy and comfort living Aliyu, (2012).

The social unrest incidence in other part of the North, for instance in Jos, took another dimension on the effect of social unrest on sales and rental value when compared to Kano State. The scenario is different in Jos because the sales and rental value of landed properties is increasing and maintaining a steady upward movement as at 2001, when the crisis in Jos took a different dimension up till now.

The wide gap between the supply and demand is gradually driving the housing bubble rent into the drain. This in turn is having a negative impact on the lending capacities of people from the bank. According to Auty,(2007) high rent diverts government incentives from wealth creation into patronage distribution that causes growth to collapse and the negative effects of high rent are amplified when rent is concentrated on governments or associated with ethnic diversity. Using the rent-cycling theory, he further observed that low rent confers incentives to create wealth because governments in low-rent economies expand their revenue by taxing an increasing output. He believed that encouraged governments to invest in public goods and maintain efficiency incentives.

Although a lot of studies has been done on conflict and violence as they affect the economy and sociopolitical conditions, not much research has been done on the impact of violence on rental value of property, most especially with the peculiar nature of the Boko Haram threat. This study analyses the impact the threat has on property value in Kano metropolis and the trend of rental growth presently when compared to previous years. 


\section{Study Area:}

Kano is one of the leading Hausa States- politically and economically. Kano State has a population of 9,383,682, according to the 2006 census. It was created on May 27, 1967. It borders Katsina State to the northwest, Jigawa State to the north-east, Bauchi State to the south-east and Kaduna State to the South-west.

Kano was a major producer of groundnuts in the 1970's. In fact, it produced about half of Nigeria's commodities as the main source of foreign exchange and government revenue. It is the largest and most important commercial centre in Northern Nigeria. Impressive infrastructural facilities such as Mallam Aminu International airport and road and rail links to other parts of the country as well as excellent road network within the state provide unique opportunities for the steady growth of commercial activities. There are over 100 branches of insurance companies and brokerage firms (www.nigeria.gov.ng/2012).

\section{Materials and Methods}

The study population is primarily the Estate Surveyors and Valuers in Kano state, who are heads of firms or heads of agency and management departments. The questionnaire was completed by these heads of departments. Efforts were made to optimise the questionnaire before distribution. It was reviewed severally to avoid any misunderstanding of questions. All the Estate firms in Kano state are located in the metropolis. There are 35 registered Estate surveying and valuation firms in Kano State using the registered list of Firms from the branch chairman as the sampling frame. The questionnaire was distributed to all the registered estate surveyors and firms but out of the 35 to whom the questionnaire was administered, only 27 responses (representing $77 \%$ response rate) were retrieved.

In addition to the questionnaire survey of estate surveyors and valuers, the author also interviewed 107 (One Hundred and Seven property owners). The interviews with property owners solicited for answers to issues relating to how often they receive briefs on agencies (letting and sales), the time it takes to complete a transaction on letting, methods used in marketing their properties, their opinion on letting out of properties at present compared to previous years. Finally, the people were asked their own opinions on whether it is viable to invest in property in Kano state, and on whether the values of properties had fallen presently and the reason(s) for it.

The sampling method employed is the convenient/judgement analysing and comparing variables which the study requires. In respect of the interview with property owners, the focus was on the viability of their properties going for rent and if they were able to maximise their returns from their investments. Descriptive statistics in form of tables and theoretical analysis were adopted for data that are not numerical in nature.

\section{Results and Discussion}

Table 1 shows the duration of professional practice among the estate surveying and valuation firms and this affirm the level of experience and expertise.

\section{Table 1: Duration of Professional Practice:}

This table shows the duration of professional practice among the estate surveying and valuation firms and this affirms the level of experience and expertise.

$\begin{array}{rccc}\text { S/No } & \text { Duration (year) } & \text { Respondent } & \text { Percentage } \\ 1 . & 1-5 & 6 & 22 \\ 2 . & 6-10 & 6 & 22 \\ 3 . & 11-15 & 8 & 30 \\ \text { 4. } & \text { More than } 15 & 7 & 26 \\ & \text { Total } & \mathbf{2 7} & \mathbf{1 0 0}\end{array}$

Table 2, shows the numbers of instructions 'to let' obtained by the estate firms before and after the Boko Haram insurgence.

\begin{tabular}{|c|c|c|c|}
\hline S/ No & Options & Respondents & Percentage \\
\hline 1. & Less than 5 & 9 & 33 \\
\hline 2. & $5-10$ & 7 & 26 \\
\hline 3. & $10-15$ & 5 & 19 \\
\hline 4. & $15-20$ & 1 & 4 \\
\hline \multirow[t]{2}{*}{5.} & More than 20 & 5 & 19 \\
\hline & Total & 27 & 100 \\
\hline
\end{tabular}

Table 2 reveals that before the crisis $33 \%$ of firms received less than 5 briefs while $67 \%$ received more than 5 with as much as $19 \%$ receiving more than 20 . This shows that most of the firms in Kano were vibrant 
and received many briefs to keep them busy on a daily basis. There was no dull moment in any firm in terms of letting of properties and there was flow of cash every week.

$\begin{array}{cccc}\text { Table 3: Instructions 'to sell' before the crisis: } \\ \text { S/ No } & \text { Options } & \begin{array}{c}\text { Respondents } \\ \text { Percentage }\end{array} & 67 \\ 1 . & \text { Less than } 5 & 18 & 22 \\ 2 . & 5-10 & 6 & 7 \\ 3 . & 10-15 & 1 & 4 \\ 4 . & 15-20 & - & - \\ 5 . & \text { More than } 20 & \mathbf{2 7} & \mathbf{1 0 0}\end{array}$

With regards to property sales, Table 3 shows that $67 \%$ received less than 5 briefs for sale in a week, which is an indication that house sales were not as common or popular as renting of houses. Only $22 \%$ received 5-10 briefs in a week. People invest in properties either for rent or developed for sale. During boom or normal periods experience has shown that sale transactions and briefs seldom come in compared to letting. This is because it normally takes a longer period to complete sale transactions as compared to letting. So this table revealed situation of market during the boom or normal period.

Tables 4 and 5 present the property market situation since the Boko Haram insurgency.

\begin{tabular}{|c|c|c|c|}
\hline S/ No & Options & Respondents & Percentage \\
\hline 1. & Less than 5 & 2 & 7 \\
\hline 2. & $5-10$ & 6 & 22 \\
\hline 3. & $10-15$ & 5 & 19 \\
\hline 4. & $15-20$ & 14 & 52 \\
\hline 5. & More than 20 & - & - \\
\hline & Total & 27 & 100 \\
\hline
\end{tabular}

From Table 4, it can be seen that only $7 \%$ of the firms received less than 5 instructions for letting as compared with $52 \%$ that received 15-20 instructions per week. Thus the numbers of instructions to let increased appreciably, which is a reflection of the high level of vacant property in the market as a result of the out migration of people from Kano. Obviously, property owners have been trying hard to get tenants into their properties so that they will not lose on their investments.

Table 5 shows the numbers of instructions to sell received during the period of social unrest.

Table 5: Instructions 'to sell' during the period of social unrest incidence (2012-2013):

$\begin{array}{rccc}\text { S/No } & \text { Background } & \text { Respondent } & \text { Percentage } \\ \text { 1. } & \text { Less than 5 } & 1 & 4 \\ \text { 2. } & 5-10 & 4 & 15 \\ \text { 3. } & 11-15 & 2 & 7 \\ \text { 4. } & 16-20 & 11 & 41 \\ \text { 5. } & \text { More than } 20 & 9 & 33 \\ & \text { Total } & \mathbf{2 7} & \mathbf{1 0 0}\end{array}$

It is quite revealing that as much as $74 \%$ received 16 and above briefs ( $41 \% 16-20$, and $33 \%$ over 20 briefs) to sell. When compared with the "boom period", that is, the period before the crisis, the "doom period", or the period of social unrest, Table 5 reveals that the numbers of instructions to sell have been high. More people have been giving out their properties to sell so as to enable them re-invest in other locations which they believe are more secure. Unfortunately, in the prevailing circumstances, few buyers would be willing to buy for fear of losing their investment.

Property whose price is supposed to be a reflection of present and future physical development and the attractiveness of living in a particular area is now subjected to market decline. Conflict and violence led to mistrust among different groups in the society, resulting in displacement and mass movement of people and, consequently, to a fall in economic activities. 
The Impact of Social Unrest on Property Values in Kano Metropolis, Nigeria.

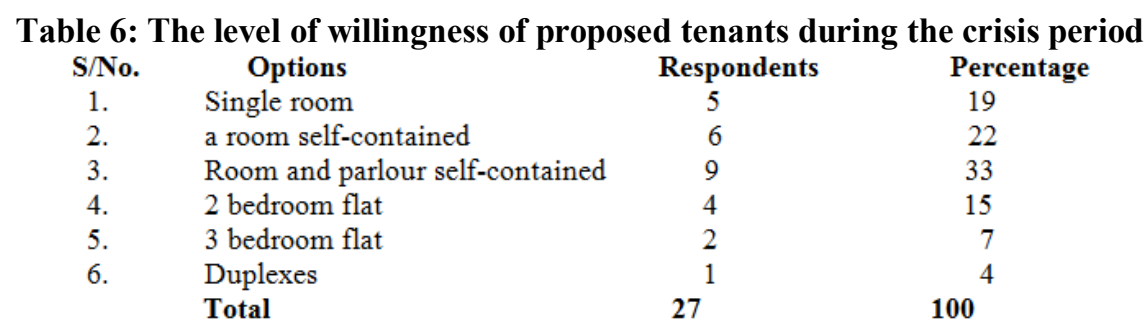

Table 6 indicates the residential preferences of tenants during the current crisis period. Only 19\% opted for single room accommodation while most opted for small and cheap apartments. This could be as a result of a number of reasons, including the need for more secure accommodation, the economic depression in the state, and the re-location of family members to other parts of the country, etc.

Table 7 indicates the respondents' views on the trend of rental values of properties for the past five years.

Table 7: Trend of rental value for 5 years

\begin{tabular}{|l|l|l|l|l|l|l|l|}
\hline S/no. & Categories & Characteristics & 2013 & 2012 & 2011 & 2010 & 2009 \\
\hline 1. & Residential & Risen & 4 & 3 & 2 & 8 & 10 \\
& & Fallen & 5 & 14 & 7 & 1 & - \\
\hline 2. & Commercial & Risen & - & - & - & - & - \\
& & Fallen & - & - & 4 & 8 & 15 \\
& & Unchanged & - & 13 & 8 & - & - \\
\hline
\end{tabular}

Property values fell in the period 2011-2013 as compared with the period 2009-2010. They fell to their lowest levels in 2012 and picked up a little in 2013. The fall apparently affected both residential and commercial property. Thus, it appears that investing in property in Kano metropolis might not be viable and this affects all facets of property investment (sales, purchase and development).

Table 8: Other reasons for fall in property value

\section{Challenges}

1. Economic depression

2. Mass movement of people

3. Lack of good rent

4. Deviation into other forms of investment

5. High cost of land

\section{No of Respondents}

9

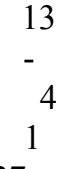

27

This table gives some of the reasons adduced for the fall in property values apart from the main one of social insecurity. The mass movement of people to other safe areas has made property value to drop, and this will has affected the economic situation of the state. Property development might be affected because of the economic depression in such areas. Deviation into other forms of investment is another option picked by people for now until the social security situation gets better.

Table 9 indicates the areas that were affected as a result of the social unrest. With the interview that was conducted among the property owners, 67 numbers of them own residential properties and 40 of them are commercial property owners. This table shows the areas affected for residential properties.

Table 9: Residential property areas mostly affected

$\begin{array}{clcc}\text { S/No. } & \text { Location of residential ppties. } & \text { Respondents } & \text { Percentage } \\ \text { 1. } & \text { Ring road/farawa } & 17 & 25 \\ \text { 2. } & \text { Hotoro } & 13 & 20 \\ \text { 3. } & \text { Tokarawa } & 7 & 11 \\ \text { 4. } & \text { Seller quarters } & 6 & 9 \\ \text { 5. } & \text { Naibawa } & 9 & 13 \\ \text { 6. } & \text { Gwarzo road } & 7 & 10 \\ \text { 7. } & \text { Farmcenter } & 4 & 6 \\ \text { 8. } & \text { Sharada } & 2 & 3 \\ \text { 9. } & \text { Ungwar Uku } & 2 & 3\end{array}$

From this table, Ring road, Hotoro and Naibawa are majorly affected with $25 \%, 20 \%$, $13 \%$. Property values in these areas had fallen according to the property owner's view. Presently from this study, the market value (sales and rental) of residential properties across the metropolis of Kano state has been on the decline; this 
is partly attributed to the forces of demand and supply. As there is mass movement out of the city the demand for properties keeps falling while the supply is on the increase. Residential areas like Hotoro quarters, Tarauni quarters, Gwarzo road, Farawa Dorayi , Badawa, are areas, where an average salary earner will want to stay due to their affordable house prices. But, since the Boko haram attack, the demand for houses has fallen drastically, such that some owners have had to reduce the rents collected on properties as compared to previous years. There is mass movement of people away from these places to other safe areas and even outside Kano.

\section{Table 9: Commercial property areas mostly affected}

$\begin{array}{clcc}\text { S/No. } & \text { Location of residential ppties. } & \text { Respondents } & \text { Percentage } \\ \text { 1. } & \text { Muritala Mohammed Way } & 9 & 22.5 \\ \text { 2. } & \text { Ibrahim Taiwo Rd. } & 3 & 7.5 \\ \text { 3. } & \text { Civic Centre } & 1 & 2.5 \\ \text { 4. } & \text { Beirut } & 5 & 12.5 \\ \text { 5. } & \text { Post office road } & 1 & 2.5 \\ \text { 6. } & \text { Bompai } & 13 & 32.5 \\ 7 . & \text { France road/Ibo road } & 8 & 20.0 \\ & & \mathbf{4 0} & \mathbf{1 0 0}\end{array}$

From the table above, Beirut, Bompai and France road are majorly affected with $12.5 \%$,

$32.5 \%, 20 \%$. Property values in these areas had fallen according to the property owner's view. There is mass movement of people away from these places to other safe areas and even outside Kano.

\section{Conclusion}

It is quite clear from the findings of this study that social unrests adversely affect the property market. Supply outstrips demand for property because of the flight of the population to safer locations. Rents and sale values are depressed and investors are wary of investing in property at such unsafe locations. Urgent measures are needed to avoid a catastrophic collapse in the property market. Such measures might include the following:

1. The estate surveyors and valuers in the state need to critically interview prospective tenants to establish their integrity, nature of work etc when it comes to renting out of apartments. It should strictly be based on professional grounds and not on personal interest.

2. Also, there is need for government in collaboration with security agents to train more staff in this line. They can help to provide information to the government and also identify the culprits. Government should also be sensitive enough to take necessary actions on the culprits involved. These trained personnel can be placed at different strategic locations in the metropolis.

3. Education and youth empowerment is also a main solution to the cause of social unrest in Kano State. The present state government is already making frantic efforts on this, but more can still be done in youth empowerment.

4. Religious leaders are supposed to be closer to the people, so through their sermons, it can really influence people. Their sermons should be constructive such as to bring peace and harmony to the community.

5. Effort should also be intensified by government to start off a ministry to effectively manage the demands and crises of ethnic and religious differences. This will improve the harmony and cooperation among different tribes and religions to achieve a positive human development in the country.

\section{References}

[1]. Adeyemi, L.O., (2006). Ethno-Religious Conflicts and the Travails of National Intergration in Nigeria's Fourth Republic.DAWODU.COM

[2]. Aliyu. A.A (2012). The Impact of Intangible Location Attributes of Residential property value in Nigeria. A ph.D Thesis submitted in fulfilment of the requirement for award of Doctor of philosophy. pp 16.

[3]. Anas. A. (2002). Residential location markets and urban transportation: Economy Theory, Econometrics and public policy Analysis: Newyork Academic Press.

[4]. Auty, R.M (2007), Rent Cycling Theory: The Resource Curse and Development Policy:

[5]. Published in Developing Alternatives; 11(1)2007,7-13.

[6]. Babangida, I.B. (2002). Ethnic Nationalities and the Nigeria State: The Dynamic and Challenges of Governance in a Plural Nigeria. Distinguish Annual Lecture, National Institute for policy and Strategic Studies, Kuru, Nigeria.

[7]. Kuye.O. (2003). Principle and Practice of Property Valuation in Nigeria. $2^{\text {nd }}$ edition.

[8]. ISBN 978- 36149-5-9; 2003

[9]. www.Kano.gov.ng/2012-10-29-11. Accessed on September, 2013. 